\title{
The medical ethics of Erasmus and the physician-patient relationship
}

W R Albury and G M Weisz University of New England, Armidale, NSW, Australia and Harley Medical Centre, Bondi function, NSW, Australia, respectively

\begin{abstract}
Desiderius Erasmus set out his views on medical ethics just over 500 years ago. Applying the characteristic approach of Renaissance Humanism, he drew upon a variety of classical sources to develop his own account of medical obligation.

Of particular interest is Erasmus's attention to the patient's duties as well as the physician's. By treating this reciprocal relationship as a friendship between extreme unequals, Erasmus was able to maintain the nobility of the medical art and at the same time deal with the culturally sensitive issue of payment for physicians' services.

The use of physician-patient reciprocity as a principle of medical ethics has until recently been considered a novel feature of nineteenth-century medical codes. As Erasmus's treatment of physician-patient reciprocity arose from a classical conception of friendship, there may be grounds for reconsidering the role of friendship in other discourses on medical ethics from the

Renaissance to the nineteenth century.

(F Med Ethics: Medical Humanities 2001;27:35-41)

Keywords: Erasmus; physician-patient relationship; friendship
\end{abstract}

\section{Erasmus and Humanism}

One of the most influential figures of the European Renaissance (ca 1300-ca 1600) was Desiderius Erasmus of Rotterdam (1466-1536). Although an ordained priest he was excused from ecclesiastical duties, partly because of chronic poor health. ${ }^{1}$ This dispensation gave him the freedom to travel extensively and to meet the leading scholars of his age - an experience which reinforced his commitment to the ideal of a pan-European society with Latin as the universal medium of learned communication.

As an exponent of Humanism, the dominant intellectual movement of his time, ${ }^{2}$ Erasmus considered that the primary aim of scholarship was to recover the culture of classical antiquity and make it relevant for one's own society. He wrote voluminously on a wide range of subjects including theology, literature, philology, education, history, morality and politics. ${ }^{3}$ These publications brought him renown throughout Europe for his eloquence and moral vision, and he was sought after by "emperors, kings and popes, all of them wanting his services as minister, bishop or cardinal". ${ }^{4}$

\section{Medicine in the works of Erasmus}

One of the many topics addressed in Erasmus's writings is the art of medicine-sometimes approached satirically and sometimes seriously, but always with an underlying moral purpose. In The Education of a Christian Prince (1516) he pursued the classical analogy between medicine and statecraft, the one ministering to the individual body and the other to the body politic. ${ }^{5}$ In other writings he developed the Christian analogy between theology and medicine, believing that "What the priest is to our souls, the physician is to our bodies".

In the work for which he is best known today, The Praise of Folly (1511), Erasmus mocked hypocrisy and incompetence in all walks of life, including medicine. ${ }^{7}$ His negative comments on physicians and medicine in this book, together with similar jibes in other works, such as his Colloquies (1518 and later editions), ${ }^{8}$ have created the impression that he had a low opinion of physicians in general. ${ }^{9}$ The fact that he was a semi-invalid for most of his adult life ${ }^{10}$ may have given him some cause for dissatisfaction with medicine and its practitioners. But he nevertheless maintained good relations with a number of eminent physicians and clearly held some of them in the highest esteem. ${ }^{11}$

With medicine as with religion and statecraft, Erasmus believed that the deficiencies of individuals should not undermine the standing of an institution. Thus when Protestant reformers asked him to side with them against the Catholic church because of abuses by the clergy - abuses which he himself had denounced in his writings - he refused to do so on the grounds that while specific practices needed reform, the institution of the church itself was not in question. In the same way, he distinguished between bad princes and the institution of monarchy, and-as we shall see belowbetween bad physicians and the institution of medicine.

Although medicine is only a minor and often incidental theme in the overall context of Erasmus's writings, he did undertake a sustained discussion of issues relating to medical ethics in his Oration in Praise of the Art of Medicine, ${ }^{12}$ a work that presents "one of the most articulate expressions of his views of the medical art" ${ }^{13}$ While it is not a formal treatise on medical ethics, the Oration, as a eulogy or speech of praise, would have been understood in the Renaissance rhetorical tradition as a discourse on virtue and vice or the noble and the base, 
particularly with regard to noble and base actions, ${ }^{14}$ and thus as an important aid to character formation. ${ }^{15}$ The ethical dimensions of the Oration would therefore have been clear to Erasmus's readers. ${ }^{16}$

Erasmus was not a physician, although the publication of his Oration apparently led some to conclude that he was. ${ }^{17}$ Neither was he a philosopher in the strict sense of the term. ${ }^{18}$ But as a Humanist scholar he was familiar with, and drew upon, the classical traditions of medicine and philosophy, and many other fields as well. By selecting from and reworking this material, Erasmus produced a statement on medical ethics reflecting his own outlook as a highly cultivated and morally committed Renaissance man of letters.

\section{Background to the Oration}

Erasmus composed his oration early in 1499 at the request of the eminent physician Ghisbertus ${ }^{19}$ whom he had recently met and who treated him for over two decades. ${ }^{20}$ Ghisbertus apparently planned to deliver the speech to students of the faculty of arts at the University of Paris, to encourage them to study medicine. ${ }^{21}$

The arts course provided preparatory training for the "higher" faculties of law, medicine and theology. "Medicine, however, lacked the intellectual prestige of theology or the opportunities for advancement found in law" ${ }^{23}$ so medical men addressed arts students on "frequent occasions" in the hope of attracting talented graduates into the profession (page 36) ${ }^{24}$ The suitability of a formal Oration in Praise of the Art of Medicine for this purpose followed from the view that bestowing praise was "akin to urging a course of action", ${ }^{25}$ since "the same things are usually praised in [a eulogy] as are advised in [deliberative oratory]" ${ }^{26}$ Throughout the Renaissance "the function of eloquence in stimulating virtuous ideas and actions was tacitly accepted....". ${ }^{27}$

The text of the Oration in Praise of the Art of Medicine was not published until 1518, when Erasmus dedicated it to another distinguished physician, Henricus Afinius. Once in print it was well received by medical humanists - one of whom Eobanus Hessus, rewrote it in verse, ${ }^{28}$ while another, Jérôme Monteux, “include[d] Erasmus's entire piece in his books on medicine". ${ }^{29}$

The speech exhibits many conventional features of Humanist oratory. One of its oddities for the modern reader is that Erasmus quotes only ancient authors and makes no reference to the works of later physicians or to his own contemporaries. This approach, however, is entirely in keeping with the conviction of Erasmus-shared by many other Humanists - that only ancient texts in Greek and Latin should be considered, "because almost everything worth learning is set forth in these two languages".

The scope of medical ethics for Erasmus In his Oration Erasmus addresses not only the physician's ethical obligations but also those of the patient. Given the rhetorical framework within which his speech operates, these issues are not treated systematically but are presented in a literary style, interwoven with classical allusions and examples, and repeated with varying emphases in different parts of the text. To assist in setting out Erasmus's position on medical ethics in a more systematic way, it will be convenient to start with a brief statement from The Education of a Christian Prince, concerning the requirements for a good doctor.

"There are three principal requirements in a medical man: first, that he be skilled in the curative arts and familiar with the resources of the body, the powers of diseases, and the treatment to use for each illness; second, that he should be sincere and not have his eye on anything except the health of the patient, for many are led on by ambition or money to the point of administering poison instead of medicine; third, that he should pay close attention and take the necessary pains."

These three requirements can be summed up as competence, beneficence and diligence. As one would expect, there are important precedents for Erasmus's position. All three requirements, for example, are found in the Galenic text, That the Best Physician is Also a Philosopher, which Erasmus knew from the first Latin edition of Galen's works, published in 1490, and which he later (1526) translated for himself from the first Greek edition of 1525. ${ }^{32}$ In the Hippocratic corpus, which Erasmus probably knew only indirectly through the writings of St Jerome, ${ }^{33}$ one can also find these three requirements - for example, competence and diligence in the treatise entitled $L a w^{34}$ and beneficence in the Oath, ${ }^{35}$ to which Erasmus refers in his Oration (page 49). ${ }^{36}{ }^{37}$ Similarly, in Christian Europe from the early fourteenth century up to Erasmus's lifetime, the penitential manuals written for the guidance of priests when hearing confession regularly identified competence, diligence and a number of specific obligations pertaining to beneficence, as the duties of a physician. ${ }^{38} 39$

In the following section we consider Erasmus's treatment of the physician's ethical obligations in these three areas, attempting at the same time to convey some of the flavour of his rhetoric.

\section{The physician's obligations}

COMPETENCE

To become competent in medicine, Erasmus argues, the physician must master an enormous body of knowledge. To begin with, he must understand "the manifold diversity of the human body; the huge variation in condition resulting from age, sex, country, climate, education, study or habit" as well as "the tens of thousands of plants that grow in different parts of the world" (page 37).

Knowledge is also required of the "many types of illnesses" from which humans suffer. Noting that the Roman author Pliny reported three hundred varieties "separately identified by his time", Erasmus adds that "new strains ... increase daily" and 
seem "to be deliberately waging war" against the art of medicine. To understand and treat these conditions properly, the physician must be able to interpret "the frequently deceptive symptoms of disease" without error (page 37).

In addition to illnesses, the physician must know about "the daily hazards of landslides, falling buildings, fractures, burns, dislocations, wounds, and the like", as well as the effects of thousands of poisons, "each requiring its own antidote". These various menaces "constitute a danger equivalent almost to the scourge of disease itself" (page 37).

Erasmus notes further that the search for remedies requires investigation of the healing properties of herbs, fruits, trees, animals, gems and even poisons, as well as the study of authoritative texts and of celestial objects (pages 37-8). Although in other writings he is sceptical about the usefulness of astrology as a guide to human affairs, here Erasmus concentrates on technical complexity, warning of "the great difficulties involved in observing the heavenly bodies" and noting that if these difficulties are not understood then often the remedy given may be poison (page 37 ). ${ }^{40}$

\section{BENEFICENCE}

For Erasmus, the "moral excellence" of medicine consists chiefly in its dedication to "saving human life" (page 49). Although the physician also has a "duty to benefit men in other ways" (page 42) which are enumerated throughout the Oration, nevertheless it is in saving lives that "the physician's beneficence approximate[s] to the divine charity" (page 41). "In times of peril" the good physician remains at the patient's bedside "to contend with the disease for the life of the critically ill, and thereby frequently puts his own life at risk" (page 46). He is in this way a "much more genuine friend" than "the common run of friends" who "in times of adversity ... fly away, like swallows at the approach of winter" (page 46). As we shall see below, this invocation of friendship is important for Erasmus's account of the patient's obligations as well as the physician's.

Erasmus cites Pliny's adage that "physicians alone are allowed to take life with absolute impunity", and he adds that they may do so "not only with impunity but also to their financial gain". So it is even more to the credit of good physicians, he argues, that they choose to save life when they have this opportunity to profit from causing death. "That they have the opportunity is due to their profession; that they decline it, to their moral integrity" (page 48). The beneficence of physicians is nowhere more evident than when "medicine in her compassion" provides treatment for detractors who heap abuse on the profession, even though physicians could easily "let them die with impunity" (page 48).

Within the medical fraternity Erasmus acknowledges that there are "some who administer poisons instead of remedies, ... some who from motives of gain or worldly ambition fail to give the sick proper attention" (pages 48-9) and some who "cheat the unwary" (page 39). Such rogues, he argues, can be found in every profession-indeed, some priests are adulterers and some monks, murderers. Thus for medicine "a good part of the problem stems not from the art itself but from either the ignorance or the self-aggrandizement of disreputable physicians" (page 45). It would be "perverse" to condemn the art of medicine because of "the shortcomings of its practitioners", so for Erasmus the solution is "that all physicians should acquit themselves as true physicians, and ... that they all should bear witness to that solemn oath which Hippocrates formulated in hallowed terms and exacted from his pupils" (page 49). ${ }^{41}$

\section{DILIGENCE}

There are two aspects to the requirement for diligence in the Oration. In the first place, diligence is needed to attain medical competence. "If excellence comes only through great labour, consider how nothing is more demanding than the study of medicine, which comprises so many disciplines" and involves such a profound investigation into so many things (page 49). To master this body of knowledge seems to demand a superhuman effort (page 38); therefore "absolute knowledge of the whole art is reserved only to the few who have dedicated a lifetime to this single branch of study" (page 45).

Secondly, the physician needs to be diligent in the application of his learning. It is not only by his "art" and "skill" but also by his "care and constant help" that the physician saves the moribund patient and "snatches him back, as it were, from the very jaws of death" (page 41). The prolongation of life "as far as is humanly possible" can be achieved only through the industriousness of physicians (page 42). In times of serious illness the good physician "is constant in his attendance" on the patient (page 46), whereas bad physicians "from motives of gain or worldly ambition fail to give the sick proper attention" (page 49). Thus, when "rendering the physician his due", it is both his "skill" and his "dedication" (or industriousness) that are to be rewarded (page 43).

\section{The patient's obligations}

The obligations of patients is not a topic routinely addressed today in medical ethics, where the emphasis tends to be on the physician. Many ancient texts, however, state that the patient has a duty to cooperate with the physician; and Galen argues that the patient should admire his physician as a god, since this attitude encourages cooperation. ${ }^{42}$ In the Oration Erasmus also assigns a god-like role to the physician, but his aim is to elicit gratitude from the patient rather than cooperation.

Three and a half centuries later, the American Medical Association's (AMA) first code of ethics (1847) included a section on patient obligation in which both cooperation and gratitude-and a number of other obligations-were identified. ${ }^{43}$ This formulation of medical ethics in terms of reciprocal obligations between physicians and 
patients has been considered "[a]ltogether remarkable for its time" ${ }^{44}$ In its immediate context, it can be regarded as an application of the social contract theory of John Locke and thus as "a natural outgrowth of the Americans' Lockean intellectual heritage". ${ }^{45}{ }^{46}$ But while the particular use of the principle of reciprocity found in the AMA code may seem novel when compared with the British discussions of medical ethics from which it developed, ${ }^{47-49}$ a reading of Erasmus's Oration shows there were pre-Enlightenment antecedents to the use of physician-patient reciprocity as a principle of medical ethics.

As set out in the Oration, the patient's obligations toward the physician may be summed up under two headings, gratitude and reward.

\section{GRATITUDE}

The patient's gratitude, like the physician's diligence, has two aspects. First of all, "everyone everywhere" owes gratitude to the art of medicine. “... [W] ould he not appear to outdo ingratitude itself, and be himself almost unworthy of life who did not love, honour, esteem, and revere medicine as parent, nurse, guardian, and protector of life, second only to God himself?" (page 39). The effect of this obligation of gratitude toward the institution of medicine in general, as distinct from any individual practitioner, is to underscore Erasmus's approach to failures of beneficence by some physicians. It is, he writes, unfair "to impugn the profession because some of its practitioners cheat the unwary" (page 39).

Secondly, Erasmus considers that patients owe a special kind of gratitude, bordering on reverence, to individual physicians from whom they receive treatment. "... [W] hile in the case of other benefactors it would be ungrateful for a man not to acknowledge the benefaction, in the case of the physician it would be impious, inasmuch as he protects by his skill and acts in a sense as the coadjutor of that heavenly gift which is the supreme sign of God's abundant love for us-I mean, of course, the gift of life" (page 41).

From this point it is only a small step for Erasmus to assign the physician an even more divine role. "If a man wracked by disease cannot be said to be truly living at all, and the physician either restores him to full health or keeps him out of danger, surely it is proper to acknowledge the physician as, in a sense, a giver of life" (page 42). Thus "in the case of a learned and trusty physician no honour can be deemed too high" (page 37). And while Erasmus insists that gratitude is the physician's due, he also argues that "no degree of gratitude can repay the physician for the service he has rendered" (page 46).

\section{REWARD}

The issue of repayment links the obligation of gratitude with the obligation to provide a material reward for the physician's services. It is significant that Erasmus raises this issue in the context of his discussion of friendship and his assertion that the physician is one of the most genuine of friends, whom patients should "cherish and honour ... as they would a parent" (page 46). Although the nature of friendship was an important topic for classical ethics, "moral philosophy in modern times has neglected this subject, treating it as a matter of personal choice outside moral theory". ${ }^{50}$ Humanist writers of the Renaissance followed the classical precedent of treating friendship as a social virtue, ${ }^{51}$ and Erasmus placed a particularly high value on it in his own life. ${ }^{52}$

Since the Oration rhetorically equates the physician with a parent or a demigod, it is reasonable to ask what kind of friendship could obtain between physician and patient, and what role material rewards would have in this friendship. To assist in answering this question we will draw upon Aristotle's discussion of friendship in books VIII and IX of the Nicomachean Ethics. While Humanists generally had little use for the more abstract parts of Aristotle's thought, many of them regarded his treatises on moral philosophy as valuable texts. “... [P] ractically every writer of the period was acquainted with the main doctrines of Aristotelian ethics and was inclined to adopt them or to discuss them". ${ }^{53} 54$

This is not to suggest, however, that Erasmus necessarily drew directly or exclusively upon the Nicomachean Ethics for his Oration, since many elements in Aristotle's discussion of friendship were taken up by later authors such as Cicero $^{55}$ and Seneca, ${ }^{56}$ both of whose moral doctrines "continued to exercise a widespread influence during the Renaissance ...." ${ }^{57}$ Indeed, at around the same time as he composed the Oration Erasmus was preparing an edition of Cicero's Offices, ${ }^{58}$ a text which also addresses some of the ethical dimensions of friendship and gratitude. ${ }^{59}$ But the Aristotelian account is the most comprehensive one on this topic and provides the easiest reference point for understanding Erasmus's position in the Oration.

\section{Friendship}

The classical ideal of friendship was a deep relationship between two virtuous equals, based on a mutual recognition of their virtue and without concern for practical or material gain. As Aristotle acknowledged, however, "it is natural that such friendships should be infrequent; for such men are rare". ${ }^{60} \mathrm{He}$ therefore recognised "another kind of friendship, viz that which involves an inequality between the parties, for example that of father to son ...". ${ }^{61}$

This kind of friendship between unequals provides a model to help us understand the role of gratitude and material reward in Erasmus's medical ethics. "...[W] hen children render to parents what they ought to render to those who brought them into the world, and parents render what they should to children, the friendship of such persons will be abiding and excellent". ${ }^{62}$ The question, then, is to determine what, in an unequal friendship, the patient "ought to render" to the physician in recog- 
nition of the latter's beneficence in saving or prolonging life.

The subject of material rewards for the physician's services is a delicate matter for Erasmus to raise. ${ }^{63}$ Firstly, in a culture of honour, which the Oration evokes, to associate an activity with payment detracts from its nobility. On the one hand, the nobility of the actor is impugned, for "honour is the prize of virtue and of beneficence, while gain is the assistance required by inferiority" ${ }^{64}$ And on the other hand, the nobility of the action itself is undermined, for "if we make merchandise of benefits, all the merit of so fine an action will perish" ${ }^{65}$ Thus Erasmus must maintain that medicine is too grand "to concern itself with the slavish pursuit of pecuniary profit: that is the hallmark of the base arts" (page 47).

Secondly, having identified the desire for money as a moral failing that turns physicians into poisoners (page 48), he cannot suggest that they act with any thought of reward. "The distinguished physician, like some divinity, saves life free of charge...". Even a legally enforceable payment is cast in terms of a spontaneous offering, to avoid any hint of a contractual relationship that would turn the reciprocal virtues of beneficence and gratitude into a morally neutral quid pro quo. "... . [I]t is impiety not to acknowledge the service of a divinity. The physician may care nothing for payment, but you deserve the full severity of the law for your signal ingratitude" (pages 47-8). ${ }^{66}$

For all his reticence in taking up the matter of riches, once he embarks on this topic Erasmus warms to it considerably.

"If there really are people who prefer to evaluate things in terms of their utility and profitability, albeit this art is too sacred to be appraised in terms such as these, then not even in this respect does medicine yield precedence to any of the other arts. For no art has been more profitable or as convenient for providing instant earnings." (page 47)

The average annual income for a physician of Erasmus's day was 16 golden florins, as compared with 12 for a baker. The 1525 Greek edition of the works of Galen cost 30 golden florins, unbound. ${ }^{67}$ These figures suggest that medicine provided a comfortable income rather than a lavish one. Erasmus, however, claims that "several examples would ... readily spring to anyone's mind, of men today whom this art has made as rich as Croesus"indeed, even uneducated quacks can make a good living at it (page 47)

Nevertheless, despite its income-generating capacity, "medicine ... can never receive full recompense" (page 47). The patient offers to the physician both gratitude in the form of honour and reward in the form of payment, yet neither can repay the physician for his services. This situation is characteristic of the most extreme form of friendship between unequals considered by Aristotle:

“...[F] riendship asks a man to do what he can, not what is proportional to the merits of the case; since that cannot always be done, for example, in honours paid to the gods or to parents; for no one could ever return to them the equivalent of what he gets, but the man who serves them to the utmost of his power is thought to be a good man." 68

While the passage just quoted deals with honour, Aristotle makes a similar comment in his discussion of monetary payments.

"And so too, it seems, should one make a return to those with whom one has studied philosophy; for their worth cannot be measured against money, and they can get no honour which will balance their services, but still it is perhaps enough, as it is with the gods and with one's parents, to give them what one can." $" 69$

By using terms reminiscent of Aristotle's analysis of friendship between extreme unequals, Erasmus represents the physician-patient relationship as a friendship based on virtue rather than on utilitarian exchange. Through the virtue of beneficence, and not through hope of gain, the god-like physician provides "the gift of life" (page 41). The patient's return of honour and material reward is also based on virtue and not on calculation, because the debt is incalculable. The aim of the patient should not be to offer recompense but "to acknowledge the service of a divinity" (page 48), and to do so "to the utmost of his power". ${ }^{68}$ It is this intention to do the utmost that especially makes the patient's response an act of virtuous friendship, "for it is purpose that is the characteristic thing in a friend and in virtue". ${ }^{70}$

Like the Hippocratic oath, the Erasmian view of medical ethics establishes a set of obligations which only a few individuals may fully satisfy. But, as Erasmus writes of the oath, this fact should not detract from its value as an ideal- "nor should we cease striving to live up to its lofty demands because we observe it being neglected by very many" (page 49).

\section{Conclusions}

In his Oration in Praise of the Art of Medicine Erasmus presents a view of medical ethics that identifies competence, beneficence and diligence as the physician's primary moral obligations. The activity of the physician, when directed toward the patient in accordance with these obligations, gives rise to reciprocal obligations on the part of the patient: gratitude and reward. The activity of the patient in accordance with these obligations returns honour and payment to the physician.

Erasmus keeps this reciprocal relationship within an ethical framework, and protects it from interpretation as a morally neutral quid pro quo, by characterising it in a way that is similar to the discussion in Aristotle's Nicomachean Ethics of friendship between unequal parties in its most extreme form - the form in which the contribution of one party can never be repaid by the other. The recipient of the benefit offers honour and material rewards to the benefactor, not in order to pay a debt 
but to do the utmost to acknowledge the benefaction. In this ethical context, the usual incompatibility between honour and payment does not apply.

Given the role which this specifically ethical concept of friendship plays in Erasmus's account of the physician-patient relationship, there may well be grounds for re-examining references to friendship in later writings on medical ethics. In the seventeenth century, Aristotelian ethics was still "part of the university education shared by physicians" ${ }^{71}$ By the eighteenth century, in Protestant areas at least, Aristotelian moral philosophy was being replaced by new versions of natural law theory $;^{72}{ }^{73}$ but as this latter tradition stretched back to writers such as Cicero and Seneca, some elements of the classical doctrine of friendship could easily have been retained. It remains to be explored whether any such elements influenced nineteenth century views of physician-patient reciprocity. ${ }^{74}$

While Erasmus's Oration in Praise of the Art of Medicine does not cover all aspects of medical ethics, it does set out a coherent view of the ethical relationship between physician and patient, based on classical notions of unequal friendship. Consideration of this view casts light on the moral outlook of one of the most important Humanist scholars of the Renaissance, and it also provides historica background to the use of physician-patient reciprocity as a principle of medical ethics in the nineteenth century.

W R Albury, BA, PhD, is Professor and Dean of the Faculty of Arts, University of New England, Armidale, NSW, Australia. G M Weisz, MD, FRACS, is a Consultant Orthopaedic Surgeon in the Harley Medical Centre, Bondi function, NSW, Australia.

\section{References}

1 Krivatsky P. Erasmus's medical milieu. Bulletin of the History of Medicine 1973;47:114.

2 Kristeller PO. Renaissance thought: the classic, scholastic and humanist strains. New York: Harper Torchbooks, 1961.

3 Erasmus D. Collected works of Erasmus. Toronto/Buffalo/ London: University of Toronto Press, 1974- (86 volumes planned)

4 O'Malley CD. Desiderius Erasmus: the spirit and the flesh. fournal of the American Medical Association 1971;216:66

5 See reference 3:27 (1986): 242-3, 266-7. Erasmus D. The education of a Christian prince [Institutio principis Christiani]. cation of a Christian prince [Ins

Cheshire NM, Heat

6 See reference $1: 119$

7 See reference 3: 27 (1986): 107, 115, 118. Erasmus D. The praise of folly [Moriae encomium]. Radice $\mathrm{B}$, trans.

8 See reference 3: 39-40 (1997). Erasmus D. Colloquies [Familiarum colloquiorum formulae]. Thompson CR, trans.

9 Huizinga J. Erasmus and the age of reformation. New York: Harper Torchbooks, 1957:119.

10 See reference 4: 66-70.

11 See reference 1: $113-54$ and reference 10.

12 See reference 3: 29 (1989): 31-50. Erasmus D. Oration in praise of the art of medicine [Declamatio in laudem artis medicae (Encomium medicinae)] McGregor B, trans.

13 See reference 1: 118

14 Aristotle. Rhetoric. Roberts WR, trans. In: McKeon R, ed. The basic works of Aristotle. New York: Random House, 1941: 1353-9 (I, 9).

15 Quintilian. Institutio oratoria [vol 1]. Butler HE, trans. London: William Heinemann, 1953: 235

16 It has been suggested that Erasmus's praise for medicine in this work is "possibly overblown," in view of its rhetorical genre. (Schleiner W. Medical ethics in the renaissance. Washington, DC:
Georgetown University Press, 1995: 205.) This criticism might diminish the value of the Oration as a source of factual information about medicine in Erasmus's time, but it does not affect the status of the work as an exercise in moral exhortation.

17 Domanski J. Introduction [to his Latin edition of Encomium medicinae]. In: Erasmus D. Opera omnia [vol 1.4]. Amsterdam: North-Holland Publishing Co, 1973: 154.

18 See reference 2: 102 .

19 For the identification of Ghisbertus as Ghisbert Hessels, see Godin A. Ghisbert. In: Bietenholz PG, Deutscher TB, eds. Contemporaries of Erasmus: a biographical register of the Contemporaries of Erasmus: a biographical register of the
renaissance and reformation [vol 2]. Toronto/Buffalo/London: renaissance and reformation [vol 2]. Toro

20 See reference 1: 129

21 See reference 17: 147

22 Bullough VL. The development of medicine as a profession: the contribution of the medieval university to modern medicine. Basel/New York: Karger, 1966: 48, 69.

23 See reference 22: 109 .

24 Bracketed page numbers refer to the English text of the Oration, reference 12.

25 See reference 14: 1357

26 See reference 15: 479 .

27 Woodward WH. Desiderius Erasmus concerning the aim and method of education. New York: Columbia University Teachers College, 1964: 122 .

28 See reference 17: 151

29 See reference 16: 205

30 See reference 3: 24 (1978): 667. Erasmus D. On the method of study [De ratione studii]. McGregor $\mathrm{B}$, trans.

31 See reference 5: 242-3.

32 See reference 3: 29 (1989): 245-8. Galen. The proper physician [Qualem oporteat esse medicum (Galeni quod optimus medicus idem sit et philosophus)]. Rummel E, trans.

33 See reference 17: 155.

34 Anonymous. Law. Jones WHS, trans. In: Reiser SJ, Dyck AJ, Curran WJ, eds. Ethics in medicine: historical perspectives and contemporary concerns. Cambridge MA/London: MIT Press, 1977:

35 See reference 34: 5. Anonymous. Oath. Jones WHS, trans.

36 Among physicians, as distinct from moralists, serious interest in the Hippocratic Oath was a fairly recent phenomenon in Erasmus's day, probably stimulated by Humanist scholarship. It was around this time that editions of the mediaeval medical textbook compilation, the Articella first began to include the textbook compilation, the Articella, first began to include the Oath and the Law. French R. The medical ethics of Gabriele de Zerbi. In: Wear A, Geyer-Kordesch J, French R, eds. Doctors and ethics: the earlier historical settin

37 It was also at about this same time that the Oath was first sworn by medical students at European universities. Nutton V. Beyond the Hippocratic Oath. See reference 36: 27.

38 Amundsen DW. Medical ethics, history of: Medieval Christian Europe. In: Reich WT, ed. Encyclopedia of bioethics [revised ed, vol 3]. New York: Simon \& Schuster Macmillan, 1995:1528.

39 Amundsen DW. Medicine, society, and faith in the ancient and medieval worlds. Baltimore: Johns Hopkins University Press, 1996: $253 \mathrm{ff}$.

40 See reference 39: 207. It was customary in Erasmus's time to distinguish between licit "natural astrology" and illicit "super-
stitious astrology". The first was concerned with the physical influence of celestial bodies 0 influence of celestial bodies on such things as the weather and health or illness, while the second was concerned with the pre-

41 See reference 16: 6, 15. The distinction here between

"physicians" and "true physicians" parallels the assertion in the "physicians" and "true physicians" parallels the assertion in the stage, who are not really the characters they portray, but only stage, who are not really the characters they portray,

42 Amundsen DW. Medical ethics, history of: ancient Greece and Rome. In: Reich WT, ed. Encyclopedia of bioethics [vol 3]. New York: Free Press; London: Collier Macmillan, 1978: 931-2.

43 See reference 34: 31-2. American Medical Association. First code of medical ethics.

44 See reference 42: 966. Burns CR. Medical ethics, history of: North America: seventeenth to nineteenth century.

45 Baker R. The history of medical ethics. In: Bynum WF, Porter $\mathrm{R}$, eds. Companion encyclopedia of the history of medicine [vol 2]. London/New York: Routledge, 1993: 868.

46 Baker R. Deciphering Percival's code. In: Baker R, Porter D, Porter R, eds. The codification of medical morality: historical and philosophical studies of the formalization of western medical morality in the eighteenth and nineteenth centuries [vol 1]. Dordrecht/ Boston/London: Kluwer, 1993: 189. 
47 Burns CR. Reciprocity in the development of Anglo-American medical ethics, 1765-1865. In: Proceedings of the XXII international congress of the history of medicine [vol 1]. London: Wellcome Institute of the History of Medicine, 1974: 813-9.

48 Burns CR. Reciprocity in the development of Anglo-American medical ethics, 1765-1865. In: Baker R, Porter D, Porter R, eds. The codification of medical morality: historical and philosophical studies of the formalization of western medical morality in the eighteenth and nineteenth centuries [vol 2]. Dordrecht/Boston/ London: Kluwer, 1993: 135-43.

49 For a different interpretation, which identifies a longer tradition of ethical discourse relating to reciprocal obligation, see Hakonsen L Medicine and morals in the enlightenment: see Hakonss L Fohn Gregory, Thomas Perciud

( Cooper JM. Friendship.

(n) Becker LC, Becker CB, eds. Ency clopedia of ethics [vol 1]. New York/London: Garland, 1992: 388.

51 Kristeller PO. Renaissance thought II: papers on humanism and the arts. New York: Harper Torchbooks, 1965: 63.

52 Schoeck RJ. Erasmus of Europe: the making of a humanist, 1467 1500. Edinburgh: Edinburgh University Press, 1990: 103-6, 141.

53 See reference 51:34, 29.

54 On this point see also Schmitt CB. Aristotle's ethics in the sixteenth century: some preliminary considerations. In: Schmit $\mathrm{CB}$. The Aristotelian tradition and renaissance universities. London: Variorum, 1984: article VII.

55 Cicero. Laelius on friendship. In: De senectute, de amicitia, de divinatione. Falconer WA, trans. London: William Heinemann, 1953.

56 Seneca. On benefits. In: Moral essays. Basore JW, trans. Cambridge MA: Harvard University Press, 1935.

57 See reference 51: 35

58 See reference $52: 248$

59 Cicero. De officiis. Miller W, trans. London: William Heinemann, 1913: 51, 59, 235, 243-5.
60 Aristotle. Nicomachean ethics. Ross WD, trans. See reference 14: 1061 (VIII, 3).

61 See reference 60: 1065 (VIII, 7)

62 See reference 60: 1066 (VIII, 7)

63 In the Renaissance the traditional view of payments to physicians as honoraria, or gifts, is replaced by the concept of salarium, or a fee that is fixed, usually by contract. This situation imposes the same difficulties on medical authors as it does on Erasmus. "Physician writers begin to think of their emolumentum as salarium rather than honorarium and thus must make the case for the nature and dignity of their work and their skills" Jonsen AR A short history of medical ethics. New York/Oxford: Oxford University Press, 2000: 44 . 64 See reference 60: 1075 (VIII, 14).

65 See reference 56: 153

66 See reference 36:77. Medical writers of the time did, of course, care about payment; but like Erasmus they were concerned that care about payment; but like Erasmus they were concerned that
the method by which they obtained their fees should be the method by which they obtained their fees should be consistent with the dignity of the profession. Gabriele de Zerbi,
for example, complained in 1495 that when doctors have for example, complained in 1495 that when doctors have "it makes our art look ignoble".

67 See reference 1: 117

68 See reference 60: 1076 (VIII, 14).

69 See reference 60: 1077-8 (IX, 1)

70 See reference 60: 1077 (IX, 1)

71 See reference 36: 108. Wear A. Medical ethics in early modern England.

72 See reference 36: 172-4. French R. Ethics in the eighteenth century: Hoffmann in Halle.

74 See reference $49: 155-8$. In her analysis of the founding figures of Anglo-American medical ethics, for example, Haakonssen's treatment of equal and unequal friendship tends to focus on the extent of social and intellectual equality between physician and patient, rather than on the question of the inequality of the patient, rather than on the question of the inequality
roles inherent in the physician-patient relationship itself. 